\title{
LAS POTESTADES Y PRIVILEGIOS DE LA ADMINISTRACIÓN PÚBLICA EN EL RÉGIMEN ADMINISTRATIVO CHILENO*
}

\author{
Juan Carlos Ferrada Bórquez **
}

\begin{abstract}
RESUMEN
El Derecho Administrativo, desde la perspectiva del Derecho europeo continental, es visto como un conjunto de principios y normas jurídicas que regulan la organización, los medios y las formas de actuación de ésta, con un contenido distinto del que poseen las normas que regulan las relaciones entre los sujetos privados. Lo anterior se afirma, esencialmente, sobre la singularidad de los intereses o bienes jurídicos que tutela -los intereses generales-, lo que le permite gozar de potestades públicas y privilegios. Estas notas características también están presentes en el Derecho chileno, pero su contenido y extensión son muy discutidos, llegándose incluso a cuestionar por algunos su constitucionalidad. Determinar sus fundamentos, manifestaciones, contenido y relación con el Estado constitucional de Derecho son las temáticas que aborda el presente trabajo.
\end{abstract}

$$
\text { POTESTADES PÚBLICAS - PRIVILEGIOS - ESTADO DE DERECHO }
$$

\section{Powers and prerogatives of the public agencies in the Chilean administrative system}

\begin{abstract}
From the point of view of the systems of civil law, Administrative Law is considered to be a body of principles and rules regulating the organization of the public agencies, its means and ways of proceeding, with a different content of those rules that regulate relations between private subjects. This has been stated essentially on the basis of the particularity of the legally protected interest - the general interest - which allows for the public agencies to utilise public powers and prerogatives. These characteristic qualities are also present in the Chilean Administrative System, although their content and extension have been subject of much debate, and even their constitutionality has been questioned by some scholars. The present work aims to determine which these characteristics are, their fundaments, manifestations, content and their relation with the Rule of Law in a constitutional State.
\end{abstract}

\section{PUBLIC POWERS - PREROGATIVES - RULE OF LAW}

* Este trabajo forma parte del proyecto de investigación FONDECYT N 1050395 (2005-2007), titulado "Hacia una construcción de una teoría general del Derecho Administrativo chileno: sus nuevos principios en el actual Estado constitucional de derecho", del que el autor es el investigador principal.

** Abogado, Doctor en Derecho, profesor de Derecho Administrativo Universidad Austral de Chile, casilla 567, Valdivia, Chile. Correo electrónico: jferrada@uach.cl Artículo recibido el 14 de mayo de 2007 y aceptado para su publicación por el Comité Editorial el 22 de octubre de 2007. 


\section{INTRODUCCIÓN}

$\mathrm{E}$ 1 Derecho Administrativo ha sido definido tradicionalmente como "el Derecho de la Administración Pública", ${ }^{1}$ es decir, un conjunto de principios y normas jurídicas que regulan la organización, los medios y formas de actuación de los órganos que forman parte de aquella, con un contenido distinto del que poseen las normas que regulan las relaciones entre los sujetos privados. ${ }^{2}$ En otras palabras, se trata de un derecho específico y singular que opera en razón del sujeto cualificado que interviene (la Administración Pública) y donde los poderes jurídicos de ésta y los derechos de las personas que actúan como fundamento y contrapeso están afectados por la tutela de los intereses públicos comprometidos.

Esta concepción del Derecho Administrativo, propia del Derecho europeo continental, y algo alejado de las concepciones anglosajonas liberales clásicas del siglo $\mathrm{XIX}^{3}$, supone la afirmación de potestades públicas específicas a favor de los órganos de la Administración del Estado, los cuales están construidos como poderes-deberes finalizados, orientados a la satisfacción de un interés público. Así las potestades de los órganos de la Administración del Estado, como los privilegios de que están provistos, tienen su fundamento y explicación en los intereses públicos o bienes jurídicos a que están asociados, lo que determina el campo de acción de las mismas potestades.

Como contrapartida de lo anterior, el Derecho Administrativo, bajo esta concepción, establece un conjunto de normas que regula pormenorizadamente el ejercicio legítimo de estas potestades, disponiendo requisitos estrictos para su constitución y funcionamiento regular. Además, y como corolario, se consagran una serie de derechos de resistencia, impugnación y reparación de las personas frente al ejercicio irregular de las potestades públicas, habilitándose mecanismos administrativos y judiciales para ello.

No obstante que los principios y reglas sobre las que se construyen estas potestades administrativas son bastante obvias y compartidas en los sistemas jurídicos del mismo origen, en el Derecho Administrativo chileno han venido siendo discutidos y puestos en duda en el último tiempo, pero no de una forma general y sistémica, sino episódica, a propósito del ejercicio de algunas potestades públicas o la utilización de ciertos "privilegios" por parte de los órganos de la Administración del Estado, los que se encuentran expresamente reconocidos en el ordenamiento jurídico. Así el ejercicio de las potestades revocatoria e invalidatoria para dejar sin efecto actos administrativos dictados con anterioridad, la potestad de autotutela para declarar y ejecutar administrativamente un derecho o el simple privilegio de presunción de validez de los actos administrativos

${ }^{1}$ García de Enterría, E. y Fernández, T.R., Curso de Derecho Administrativo, tomo I, Cívitas, Madrid, $7^{\mathrm{a}}$ edición, 1996 , p. 25.

${ }^{2}$ Ver, en este sentido, Santamaría Pastor, J. A., Principios de Derecho Administrativo General, Iustel, Madrid, $1^{a}$ edición, reimpresión, 2005, pp. 59-60, y Parada, R., Derecho Administrativo, Marcial Pons, Madrid, 9a edición, 1997, pp. 12-13.

${ }^{3}$ Por todos, Dicey, A., Introduction to the study of the Law of the Constitution, Liberty Fund, Indianapolis, 1982, reimpresión $8^{a}$ edition, 1915, pp. 213-267. 
como paso previo a la autotutela del mismo, han sido severamente cuestionados por un sector de la doctrina nacional, ${ }^{4}$ planteando incluso su inconstitucionalidad sobre la base de principios y derechos constitucionales genéricos -aplicados en forma estricta- y privilegiando claramente los derechos e intereses individuales frente a las potestades públicas.

En este contexto, este trabajo pretende analizar cómo están configuradas en nuestro Derecho Administrativo las potestades públicas y los privilegios de que gozan los órganos de la Administración del Estado y cómo deben ser entendidos ellos en nuestro actual Estado constitucional de Derecho. Al efecto, el trabajo se estructurará en cuatro apartados, correspondiéndole el primero de ellos a los principios estructurales del Derecho Administrativo chileno, especialmente en el ámbito de las potestades públicas; el segundo a las potestades administrativas en general y algunas de especial relevancia para nuestro derecho; el tercero se dedicará al estudio de algunos de los privilegios de que goza la Administración para ejercer sus potestades públicas; y el cuarto y último hará una breve relectura de estas potestades y privilegios en el marco de nuestro Estado constitucional de Derecho.

\section{Los principios y Características del Derecho Administrativo CHILENO}

\section{a. El Derecho Administrativo como producto bistórico}

El Derecho Administrativo, en los términos que lo conocemos hoy, sin ninguna duda es un derecho construido históricamente y donde sus notas características derivan de las circunstancias políticas en las que se generó y desarrolló. En palabras más certeras y fundadas de Villar Palasí, 5 "el Derecho administrativo no es una creación pacífica de la razón, o un producto de usos y costumbres juridizados -como sucede en gran parte del Derecho mercantil-, sino el resultado de la incesante y eterna polémica del poder en la Sociedad, como un subproducto -ingente, pero derivativo- de la Política, a modo de un epifenómeno de la misma”.

Esto, que parece ser una nota común en el ámbito del Derecho Público, ${ }^{6}$ en el campo del Derecho Administrativo es más evidente, ya que éste surge disciplinariamente

\footnotetext{
${ }^{4}$ Por todos, Soto, E., "La Ley 19.880 sobre procedimientos administrativos, ¿'Aleluya' o 'Miserere'?”, en Ley 19.880, sobre procedimientos administrativos. Conferencias Santo Tomás de Aquino, Academia de Derecho Santo Tomás de Aquino. Universidad Santo Tomás, Santiago, 2003, pp. 92-103.

${ }^{5}$ Villar Palasí, J.L., Técnicas remotas del Derecho Administrativo, Instituto Nacional de Administración Pública, Madrid, 2001, p. 14.

${ }^{6}$ Triepel destaca esta conexión entre los fines de la política y el derecho, poniendo como ejemplo la importancia de los primeros en la formulación de las doctrinas más relevantes del derecho público alemán del diecinueve. Así el autor citado señala que "la Jurisprudencia constructiva de conceptos, sin embargo, no se ha reducido en el Derecho público a la utilización consciente o inconsciente de consideraciones de finalidad política en el tratamiento de modestos problemas concretos". Y añade: "No es ninguna exageración
} 
como un subproducto del nuevo modelo de Estado alumbrado tras la revolución francesa, y en la que las reglas de organización y funcionamiento del poder público sufren una mutación conceptual y de contenido radical. ${ }^{7}$ Esto explica que la amplia mayoría de la doctrina sitúe el origen del Derecho Administrativo inmediatamente producida la gloriosa revolución liberal, identificando el periodo previo como la prehistoria del Derecho Administrativo, ${ }^{8}$ aunque sin desconocer la existencia en ese período de algunas instituciones relevantes para la formulación posterior. ${ }^{9}$

En este sentido, las notas y características actuales del Derecho Administrativo encuentran su antecedente más directo en el Derecho público francés de principios del XIX, donde bajo la influencia notable del Consejo de Estado se dio vida a unas instituciones y conceptos jurídicos desconocidos hasta ese momento. ${ }^{10}$ Así la formulación contemporánea de un régimen de Derecho común de la potestad pública sobre la base de los principios de separación de poderes, legalidad y responsabilidad, unido al establecimiento de un régimen particular de los actos administrativos ${ }^{11}$, serán planteamientos que influirán en forma decisiva en la configuración de los ordenamientos jurídicos administrativos.

El impacto que tuvo lo anterior en el resto de Europa continental parece insoslayable, apreciándose nítidamente la recepción de esta concepción renovada del Derecho Público en el Derecho italiano ${ }^{12}$ y español ${ }^{13}$, y en menor medida, producto de su propio

si digo que la mayoría de las teorías sobre el Estado que han llegado a ser determinantes para el Derecho público, y que en gran parte han sido construcciones jurídicas, fueron enunciadas atendiendo a metas políticas y empleadas para justificación de actos de esta misma índole. Las teorías del pacto social o estatal, de la soberanía, de la división de poderes, no han sido únicamente resultado de la especulación teórica, sino que desde un principio han constituido puntos de apoyo de finalidades políticas del Estado o de la Iglesia". Y luego prosigue: "La misma teoría de Laband sobre la contraposición entre ley en sentido material y ley en sentido formal -en apariencia absolutamente neutral desde el punto de vista político- nació con la idea puesta en el conflicto presupuestario prusiano de los años sesenta; tenía, sin duda alguna, una tendencia política, y la pasión con la que fue combatida por Hänel poseía un trasfondo político”. Triepel, H. Derecho Público y política, Cuadernos Civitas, Madrid, $1^{\text {a }}$ reimpresión, 1986, pp. 71-72.

${ }^{7}$ García de Enterría, E., La lengua de los derechos. La formación del Derecho Público europeo tras la Revolución Francesa, Alianza Universidad, Madrid, reimpresión, 1995, pp. 181 y ss.

${ }^{8}$ Parejo, L., El concepto del Derecho Administrativo, Editorial Jurídica Venezolana, Caracas, 1984, pp. 25 y ss.

${ }^{9}$ En este sentido, pueden verse especialmente el trabajo de Villar Palasí ya citado Técnicas remotas del Derecho Administrativo, en el que se contiene una interesante conexión entre los conceptos e instituciones modernas y actuales del Derecho Administrativo con algunas instituciones similares en el Derecho medieval y canónico.

${ }^{10}$ Ver, Weil, P., Derecho Administrativo, Civitas, Madrid, 1986, pp. 41-42.

${ }^{11}$ Vedel, G., Derecho Administrativo, Biblioteca Jurídica Aguilar, Madrid, 1980, p. 53.

12 Por todos, Giannini, M.S., El poder público. Estado y Administraciones Públicas, Civitas, Madrid, 1991.

${ }^{13}$ Ver, en este sentido, el ya clásico trabajo de Santamaría Pastor, J. A., Sobre la génesis del Derecho Administrativo español en el siglo XIX (1812-1845), Iustel, Madrid, 2006. 
desarrollo histórico, el derecho alemán ${ }^{14}$. Ello tuvo también un impacto directo en el Derecho Público latinoamericano, en el que la influencia francesa primero y española después se hizo sentir desde el primer momento, no obstante las modulaciones y adaptaciones de dichas construcciones jurídicas a las instituciones criollas de origen indiano y colonial que presentaban las nuevas repúblicas. En este sentido, el caso chileno no fue una excepción, apreciándose desde un primer momento la influencia francesa en la construcción de las nuevas instituciones republicanas, sin perjuicio de las peculiaridades derivadas de sus propias circunstancias históricas ${ }^{15}$.

\section{b. El proceso de formación del Derecho Administrativo chileno}

Como ya se señaló, el Derecho Público chileno presenta desde sus orígenes unos principios y reglas que dejan en evidencia la influencia del Derecho francés en nuestro medio. Ello se hace especialmente patente en nuestra legislación y doctrina más clásica, en que las construcciones jurídicas guardan una similitud que hace evidentes sus fuentes $\mathrm{y}$ antecedentes directos.

En este sentido, el propio texto constitucional clave en la formación de nuestra república, la Carta de 1833, contendrá una serie de instituciones y normas cuya cercanía con las Constituciones francesas de fines del XIX son evidentes y no parecen admitir discusión. Ténganse como ejemplo las normas sobre la administración de justicia o el órgano peculiar denominado Consejo de Estado, cuya regulación emana sin lugar a dudas de la legislación francesa de la época. ${ }^{16}$ Lo mismo ocurrirá con la legislación de desarrollo, donde la influencia gala se hará sentir casi sin contrapeso, salvo algunas adaptaciones o modulaciones propias del sistema chileno.

Esto probablemente va a condicionar a la escasa doctrina jurídica de la época, en la que la influencia de las categorías y conceptos del derecho francés va a influir sin contrapeso en la explicación y sistematización del derecho chileno. ${ }^{17}$ Así autores como Lastarria $^{18}$ y Prado $^{19}$ van a postular la configuración de un Derecho Administrativo chileno siguiendo los postulados teóricos del Derecho francés clásico, en el que la separación estricta de las autoridades administrativas y judiciales, la división entre ordenamientos

\footnotetext{
${ }^{14}$ Una síntesis de esta evolución, con las influencias políticas y sociales en el desarrollo de la doctrina germana en el siglo XIX, puede ver en Sosa, F., Maestros alemanes del derecho público, Vol. I., Marcial Pons, Madrid, 2002.

${ }^{15}$ Ver, en este sentido, Lastarria, J.V., Estudios Políticos i Constitucionales, Imprenta, Litografía i Encuadernación Barcelona, Santiago, 1906, pero cuya primera edición corresponde a 1846.

${ }^{16}$ Sobre esta materia, puede verse la memoria de grado de Cárdenas, D., El Consejo de Estado como tribunal contencioso-administrativo bajo la vigencia de la Constitución de 1833, Facultad de Ciencias Jurídicas y Sociales, Universidad Austral de Chile, 2004.

${ }^{17}$ En el mismo sentido, Pantoja, R., El Derecho Administrativo. Concepto, características, sistematización, prospección, Editorial Jurídica de Chile, Santiago, 1996, pp. 150 y ss.

${ }^{18}$ Lastarria, J.V., Estudios Políticos $i$ Constitucionales, ob. cit.

${ }^{19}$ Prado, S., Principios elementales de Derecho Administrativo chileno, Imprenta Nacional, Santiago, 1859.
} 
jurídicos privados y públicos, la construcción de una Administración Pública centralizada y paternalista y la configuración de una justicia administrativa especializada serán notas insoslayables de la recepción del derecho galo en nuestro sistema.

Si bien esta concepción cambia parcialmente en la segunda mitad del XIX, con la aparición de autores liberales, ${ }^{20}$ de clara inspiración anglosajona ${ }^{21}$ y que manifiestan una fuerte crítica y resistencia a las concepciones clásicas del Derecho público francés, ello no va a impedir el predominio de aquella, de la mano de autores como Letelier en un primer momento ${ }^{22}$ y luego, ya vigente la Constitución de 1925, de Varas, ${ }^{23}$ Aylwin ${ }^{24}$ o Silva Cimma. ${ }^{25}$

La ruptura de este proceso se origina en la segunda mitad de la década del 70 del siglo recién pasado, en que claramente bajo la influencia de una nueva ideología política - la escuela neoliberal-se produce un cambio radical en la forma de entender la actividad administrativa, derivado de la nueva concepción de la acción del Estado. ${ }^{26}$ Así la organización administrativa estatal es vista como un aparato puesto al servicio de los agentes privados, por lo que en el ejercicio de sus actividades no puede afectar los derechos de éstos, especialmente los de contenido económico.

En este contexto, la doctrina administrativa construida al amparo desde este nuevo paradigma formulará unos nuevos principios para nuestro Derecho Administrativo, los que se derivarán de la abstención y servicialidad estatal y la primacía de los derechos e intereses privados. ${ }^{27}$ Esto implica un alejamiento de las concepciones tradicionales que había seguido el Derecho Administrativo chileno hasta ese momento, proclamando su independencia de su herencia europea continental y conectándose por el contrario con supuestas instituciones indianas e hispánicas, llegando a afirmar su plena originalidad conceptual. Ello se extremará hasta una reconstrucción total del Derecho Administrativo del siglo XIX, lo que será utilizado como fundamento de una tradición liberal que niega

${ }^{20}$ Ver Huneeus, J., La Constitución ante el Congreso, Vol. II, Imprenta de Los Tiempos, Santiago, 1879, pp. 214 y ss., y Amunátegui, J.D., Tratado general de Derecho Administrativo, Imprenta, Litografía y Encuadernación Barcelona, Santiago, 1907.

${ }^{21}$ Es indudable la influencia de autores ingleses como Dicey en estos autores, lo que se refleja en la similitud de las críticas liberales al sistema francés de Derecho Administrativo. Dicey, A. Introduction to the study of the Law of the Constitution, ob. cit., pp. 213-267.

${ }^{22}$ Pantoja, R., El Derecho Administrativo, ob. cit., pp. 152-153.

${ }^{23}$ Varas, G., Derecho Administrativo, Editorial Nascimento, Santiago, 1940.

${ }^{24}$ Aylwin, A. y Azócar, E., Derecho Administrativo, Universidad Nacional Andrés Bello, Santiago, 1996, texto que constituye una reedición corregida y actualizada del texto clásico de don Patricio Aylwin, Derecho Administrativo, tomos I y II, Editorial Universitaria, Santiago, 1959.

${ }^{25}$ Silva Cimma, E., Derecho Administrativo chileno y comparado. Tomo I, Introducción y fuentes, Editorial Jurídica de Chile, Santiago, 1954.

${ }^{26}$ En este sentido, ver el texto fundacional de la nueva política económica chilena a partir de 1973, El Ladrillo. Bases de la política económica del Gobierno militar chileno, Centro de Estudios Públicos, Santiago, 1992.

${ }^{27}$ Por todos, Soto, E., Derecho Administrativo, Editorial Jurídica de Chile, Santiago, 1992, tomo I, p. 28 y tomo II, pp. 17-19. 
las características fundamentales de éste y su relación con el Derecho europeo continental, incluido su carácter potestativo. ${ }^{28}$

Ahora bien, es necesario precisar que esta concepción doctrinal no es absoluta, ya que habrá otros autores ${ }^{29}$ de similar inspiración que, no obstante recoger los planteamientos doctrinales generales antes expuestos y fundados en la nueva concepción política, dejarán a salvo algunos principios estructurales del Derecho Administrativo chileno de raíz francesa, afirmando el carácter potestativo de nuestro Derecho Administrativo.

El retorno a la democracia y el abandono parcial -en lo político- de los postulados estrictos del neoliberalismo en la actividad pública, llevarán a la doctrina de fines del siglo XX a retomar los postulados clásicos del Derecho Administrativo continental europeo, conectándose nuevamente con esa tradición jurídica. ${ }^{30}$ Lo anterior, evidentemente, no impide reconocer el cambio de perspectiva que significó la Constitución de 1980 para el Derecho Administrativo chileno, más aún considerando el nuevo rol que debe asumir la Administración del Estado en un modelo de Estado subsidiario como el proclamado en las bases institucionales de la Carta Fundamental, y con una fuerte protección de los derechos individuales, especialmente los de contenido económico. ${ }^{31}$ Precisamente en esta dicotomía entre la protección reforzada de los derechos e intereses privados, asegurada por la Constitución, por un lado, y la tutela de los intereses públicos, con una reafirmación de las potestades de la organización administrativa, el Derecho Administrativo chileno irá construyendo sus nuevos principios, detectándose una gran inconsistencia y contradicciones en este proceso. ${ }^{32}$

\section{Las potestades de la Administración Pública en el derecho Chileno}

\section{a. La potestad administrativa como poder jurídico finalizado}

Uno de los rasgos identificadores de este régimen administrativo de inspiración francesa es la existencia de potestades exorbitantes de la Administración del Estado, es decir, poderes jurídicos extraordinarios que no detentan otros sujetos que integran el ordenamiento.

En efecto, la potestad administrativa es un poder jurídico reconocido en el ordenamiento jurídico a los órganos de la Administración del Estado. Como señala De la

${ }^{28}$ Idem, tomo I, pp. 30 y ss. y 329 y ss.

${ }^{29}$ Ver Caldera, H., Tratado de Derecho Administrativo, Ediciones Parlamento, Santiago, 2001, y Fiamma, G., “El régimen administrativo tutelado”, en Gaceta Jurídica, No 71, 1986, pp. 7-8.

${ }^{30}$ Pantoja, R., El Derecho Administrativo, ob. cit., pp. 11 y ss.

${ }^{31}$ Pantoja, R., "El concepto de Derecho Administrativo en el Derecho chileno", en Revista de Derecho Público, No 64, 2002, p. 206.

${ }^{32}$ Ver Ferrada, J.C., "La progresiva constitucionalización del poder público administrativo chileno: un análisis jurisprudencial”, en La constitucionalización del derecho chileno, Editorial Jurídica de Chile / Universidad Austral de Chile, Santiago, 2003, pp. 80 y ss. 
Cuétara, "se trata de una parcela del poder público general, totalmente juridificada, funcionarizada al servicio de fines concretos y fraccionada en dosis medibles". ${ }^{33}$ En este sentido, la potestad administrativa es un poder jurídico que comparte las características propias de todo el poder público estatal, del que la Administración del Estado forma parte, particularmente su sometimiento estricto al Derecho, su servicio a los intereses generales y su carácter unilateral y coactivo.

Así esta potestad administrativa está entregada a los órganos de la Administración del Estado para satisfacer los intereses públicos puestos bajo su órbita competencial, lo que justifica, precisamente, la exorbitancia de su contenido y su fuerza coactiva con los ciudadanos. Ello permite identificar a éstas como potestad-función ${ }^{34}$ constitutivas al mismo tiempo de un privilegio y de una carga, lo que determina en último término los poderes especiales que se entregan a la Administración estatal. ${ }^{35}$

Lo anterior da lugar, sobre todo en los países herederos del sistema jurídico europeo continental como el nuestro, a un régimen jurídico diferenciado de las potestades públicas, en el que no tienen aplicación, por regla general, las normas civiles que regulan las relaciones entre privados, ya que los bienes jurídicos en juego son diametralmente distintos de los presentes en las relaciones entre particulares. Esto es lo que hace afirmar a Fiamma, en nuestro derecho, que nuestro "régimen jurídico-administrativo" funciona sobre la base de un ordenamiento operado por un conjunto de personas jurídicas administrativas, dotadas de potestades excepcionales cubiertas por un estatuto especial, al margen del derecho privado común. ${ }^{36}$

\section{b. Las potestades públicas en el Derecho Administrativo chileno}

En nuestro Derecho las potestades de la Administración del Estado tienen reconocimiento expreso en el ordenamiento constitucional y legal, vinculando su existencia y ejercicio a la tutela de los intereses públicos definidos por el legislador.

${ }^{33}$ De la Cuétara, J. M., Las potestades administrativas, Tecnos (Temas clave de la Constitución Española), Madrid, 1986, p. 33.

${ }^{34}$ De la Cuétara, J. M., "Potestades administrativas y poderes constitucionales: en torno al proceso de juridificación del poder”, en Revista Española de Derecho Administrativo, Cívitas, No 38, septiembre-diciembre 1983, versión CD Rom No 1-100, 1998, p. 15.

${ }^{35}$ Como señala Laubadére, "no debe suponerse que esta autonomía del derecho administrativo sea siempre en interés de la administración: las reglas especiales de derecho administrativo son a veces menos favorables para ella que las reglas del derecho civil. La teoría del riesgo en materia de responsabilidad, la de la imprevisión en materia de contratos, son ejemplos de teorías especiales de derecho administrativo favorables a los administrados. Sin embargo, el carácter exorbitante del derecho administrativo se traduce en ventajas para la administración, en particular por la existencia de prerrogativas de derecho público que no presentan analogía en el derecho privado. Estas prerrogativas son a base de coerción y se manifiestan por el empleo del acto unilateral. Ellas permiten a la administración obligar al administrado a alguna cosa y, por consiguiente, contrastan abruptamente con las técnicas del derecho privado dominadas por el principio de la igualdad de las voluntades". Laubadére, A. Manuel de Droit Administratif, Librairie Générale de Droit et Jurisprudence, $4^{a}$ edición, Paris, 1955, p. 15, citado por Vélez, J., Los dos sistemas del Derecho Administrativo, Institución Universitaria Sergio Arboleda, Santa Fe de Bogotá, 2a edición, 1996, p. 23.

${ }^{36}$ Ver Fiamma, G., "El régimen administrativo tutelado", ob. cit., pp. 7-8. 
Esto, como ya se dijo, contrario a lo que pudiera pensarse, no constituye una novedad en nuestro sistema administrativo, sino que constituye una característica de éste desde su formación. Así, tomando prestada de las concepciones europeas continentales en boga, la doctrina nacional afirmó desde sus orígenes la existencia en nuestro derecho de prerrogativas o poderes jurídicos especiales de las autoridades públicas. ${ }^{37}$ Ello llevará a la doctrina administrativa nacional más clásica a reconocer en términos generales esa potestad pública de la Administración, enumerando e identificando las específicas potestades administrativas de que están dotados los órganos que la integran -ejecutiva, de mando, disciplinaria, reglamentaria, discrecional y jurisdiccional, pudiendo existir otras que coadyuven al cumplimiento de su función institucional-, ${ }^{38}$ y poniéndolas en conexión con los fines de "servicio público" que deberían ejecutar aquellos para la tutela efectiva de los intereses generales de la población. ${ }^{39}$

Es claro que con la irrupción de las doctrinas neoliberales de mediados de la década de 1970 , como ya se dijo, se provocó un quiebre en esta concepción potestativa del Derecho Administrativo chileno, llegando al extremo de la negación de las potestades administrativas, sobre la base de afirmar en términos amplios los derechos asegurados en la Constitución de 1980, pero ello constituyó más un argumento ideológico que una reconstrucción real de nuestro sistema administrativo. Así, especialmente a partir de la construcción de derechos fundamentales de contenido económico de carácter amplísimo, algunos autores llevan a redefinir los principios del Derecho Administrativo chileno, cercenando a la Administración de las prerrogativas más típicas reconocidas en el derecho comparado. ${ }^{40}$

No obstante, esta tendencia no es uniforme, ya que, como se señaló, algunos autores que adhieren parcialmente a esta nueva concepción ideológica del rol del Estado y la Administración Pública no llegan a negar la existencia de potestades exorbitantes de esta última, aunque sí establecen limitaciones para su ejercicio. Así, Fiamma, por ejemplo, identificará al Derecho Administrativo chileno como un "régimen administrativo tutelado", en el que las prerrogativas del poder público derivan directamente del texto constitucional (Constitución de 1980) y que son consecuencia obvia del carácter estatutario del Derecho Administrativo chileno. ${ }^{41}$ Así su cercanía con los principios clásicos del Derecho Administrativo francés será evidente, no obstante su distancia en cuanto al establecimiento de un sistema de revisión judicial de los actos administrativos radicado en los tribunales ordinarios de justicia y no en un órgano de la propia Administración (Consejo de Estado). ${ }^{42}$

\footnotetext{
${ }^{37}$ Prado, S., Principios elementales de Derecho Administrativo chileno, ob. cit., p. 20.

${ }^{38}$ Silva Cimma, E., Derecho Administrativo chileno y comparado. Introducción y fuentes, Editorial Jurídica de Chile, Santiago, $4^{\text {a }}$ edición, 1996, p. 31.

${ }^{39}$ Idem, pp. 44-45.

${ }^{40}$ Soto, E., Derecho Administrativo, ob. cit.

${ }^{41}$ Fiamma, G., "El régimen administrativo tutelado", ob. cit., pp. 7-8.

${ }^{42}$ Idem, pp. 8-10.
} 
Más recientemente, como ya se expuso, la doctrina y la jurisprudencia se han encargado de reafirmar la existencia en nuestro derecho de estas potestades públicas de los órganos administrativos, las que se configuran como poderes exorbitantes frente a los derechos de los particulares, pero fundamentados en los intereses públicos que tutelan. Así habrá numerosa jurisprudencia que se pronunciará favorablemente en cuanto a reconocer potestades invalidatorias, revocatorias o de ejecución forzosa de los actos administrativos, atenuando en forma considerable los límites estrictos a su ejercicio que imponía la doctrina más citada hace algunos años. ${ }^{43}$

\section{c. Las potestades específicas de la Administración del Estado}

Las potestades administrativas son de distinta intensidad y tienen contenido diverso, aunque todas ellas están encaminadas a satisfacer los intereses públicos puestos bajo la tutela de la organización administrativa por el ordenamiento jurídico. Dentro de ellas se pueden destacar las potestades reglamentaria, de ejecución, de revisión de sus actos y sancionatoria, por nombrar las más relevantes, todas potestades exorbitantes de la Administración del Estado y que implican una posición privilegiada de ésta dentro del ordenamiento jurídico justificado en los intereses públicos puestos bajo su cargo.

La primera de ellas, la potestad reglamentaria, es una de las más intensas en el ordenamiento jurídico, ya que implica otorgar a los órganos de la Administración del Estado un poder excepcional de creación concurrente del orden jurídico y no sólo de sujeto del mismo. ${ }^{44}$ Esta potestad tiene sus antecedentes más remotos en el Derecho Administrativo chileno en la potestad normativa subordinada o de ejecución establecida a principios del XIX en el régimen administrativo francés, ${ }^{45}$ aunque rápidamente se extendió hacia ámbitos materiales autónomos - probablemente bajo la influencia de la también francesa Constitución de 1958- producto de las necesidades de regulación administrativa de sectores complejos y especializados del orden jurídico. ${ }^{46}$

Así, el Art. $32 \mathrm{~N}^{\circ} 6$ de nuestra Constitución Política reconoce una amplia potestades normativa, autónoma y de ejecución al Presidente de la República -como jefe del Gobierno y la Administración del Estado (Art. 24 CPR)-, lo que se complementa con las potestades normativas especializadas de los órganos administrativos sectoriales. Esto supone una habilitación amplísima en nuestro derecho a la Administración del Estado para participar en la creación del ordenamiento jurídico, constituyéndose en una potestad privilegiada de este sujeto para actuar en el Derecho Administrativo.

${ }^{43}$ En este sentido, puede verse, a título ejemplar, Sentencias de la Excma. Corte Suprema, "Salinas Lolic con I. Municipalidad de Viña del Mar" y "Lavín Mosquera con Subsecretario de Investigaciones”, Gaceta Jurídica, No 235, 2000, pp. 247-251 y No 274, 2003, pp. 43-48, respectivamente.

${ }^{44}$ Ver, en este sentido, Parejo, L., Derecho Administrativo, Ariel Derecho, Barcelona, 2003, pp. 296-297.

${ }^{45}$ Santamaría, J. A., Principios de Derecho Administrativo General, tomo I, ob. cit., p. 50.

${ }^{46}$ Ver, en este sentido, Silva Bascuñán, A., Tratado de Derecho Constitucional, tomo V La Constitución de 1980 Gobierno, Editorial Jurídica de Chile, 2a edición, 2000, pp. 149-153. 
La anterior potestad se complementa con la potestad de ejecución reconocida a la misma Administración, lo que le permite declarar, prima facie, el contenido de las relaciones jurídicas que traba con los particulares (potestad de autotutela declarativa). ${ }^{47}$ Esta potestad deriva del mandato general de ejecución de la ley que imponen los ordenamientos jurídicos a los órganos administrativos, y que en nuestro derecho tendría su fundamento en la propia Carta Política (Arts. 24 y 27), al menos para el Presidente de la República. ${ }^{48}$ Así, la potestad extraordinaria de poner en ejecución los contenidos normativos del ordenamiento, declarando los derechos y obligaciones que impone éste, constituiría un poder jurídico reconocido a la Administración Pública en nuestro derecho, lo que ha sido confirmado recientemente por la Ley 19.880 de Bases de los Procedimientos Administrativos (Arts. $3^{\circ}$ y 51 ). ${ }^{49}$

Por otro lado, la potestad de revisión de oficio de los actos administrativos o de revocación e invalidación de los mismos por la propia Administración del Estado, sin intervención, en principio, de los tribunales de justicia, también es una potestad excepcional reconocida en nuestro ordenamiento (Arts. 53 y 61 LBPA), aun cuando sus límites son imprecisos y discutidos. ${ }^{50}$ Cierto es que la doctrina nacional discutió muy arduamente la existencia de esta potestad hasta antes de la entrada en vigencia de la LBPA, ${ }^{51}$ pero dicha discusión parece no tener sentido actualmente atendiendo el texto literal de la normativa antes citada. ${ }^{52}$

La jurisprudencia de nuestros tribunales parece no tener dudas actualmente de la existencia de esta potestad exorbitante de la Administración del Estado en nuestro derecho, pero, como se señaló, los problemas están dados por los límites que deben operar para su ejercicio. Esto se ha hecho particularmente complejo a propósito de la potestad para invalidar actos administrativos, donde el "derecho constitucional de propiedad" y la interdicción de las comisiones especiales han jugado como cláusulas generales e imprecisas de limitación a las prerrogativas del poder público. ${ }^{53}$

${ }^{47}$ García de Enterría, E. y Fernández, T.R., Curso de Derecho Administrativo, tomo I, ob. cit., pp. 491-493.

${ }^{48}$ Fiamma, G., "El régimen administrativo tutelado", ob. cit., p. 8.

${ }^{49}$ Ver, en este sentido, Cordero Q., E., "La eficacia, extinción y ejecución de los actos administrativos en la Ley N $\mathrm{N}^{\circ}$ 19.880", en Acto y Procedimiento Administrativo, Segundas Jornadas de Derecho Administrativo. ACTAS. Ediciones Universitarias de Valparaíso, Pontificia Universidad Católica de Valparaíso, Valparaíso, s.f., pp. 109-130.

${ }^{50}$ Ferrada, J.C., "La potestad invalidatoria de los órganos de la Administración del Estado", en Acto y Procedimiento Administrativo, Segundas Jornadas de Derecho Administrativo. ACTAS. Ediciones Universitarias de Valparaíso, Pontificia Universidad Católica de Valparaíso, Valparaíso, s.f.

${ }^{51}$ Por todos, Soto, E., "La invalidación de los actos administrativos en el derecho chileno", en Revista de Derecho y Jurisprudencia, tomo LXXXV, No 3, septiembre-diciembre 1988, págs. 157-167.

52 En este sentido puede verse, Soto, E., "La Ley 19.880, sobre procedimientos administrativos, ¿Aleluya' o 'Miserere'?”, ob. cit., p. 96.

${ }^{53}$ Ver, en este sentido, Ferrada, J.C., "La progresiva constitucionalización del poder público administrativo chileno: un análisis jurisprudencial”, ob. cit., pp. 80 y ss. 
Por último, la potestad sancionadora es aquella que reconoce a los órganos de la Administración -como a los tribunales- la capacidad de imponer sanciones administrativas a los particulares en caso de infracción de ciertos deberes jurídicos establecidos en el ordenamiento jurídico. ${ }^{54}$ Esta potestad, pese a no estar expresamente reconocida en nuestra Carta Fundamental, se encuentra recogida en diversas leyes administrativas, atribuyéndole a órganos especializados de la Administración del Estado el poder jurídico para imponer sanciones en conformidad a la ley. ${ }^{55}$

Si bien algún sector doctrinal ha discutido la procedencia de esta potestad de la Administración en nuestro ordenamiento, la mayoría de la doctrina ha reconocido la plena vigencia de esta potestad, lo que ha sido ratificado por el Tribunal Constitucional en reiteradas ocasiones (entre otras, STC 244/1996 y, más recientemente, STC 480/2006). No obstante, lo que aún genera discusión es la aplicación a su respecto de los derechos constitucionales establecidos en la Constitución para el ejercicio de la potestad sancionadora de los tribunales de justicia en materia penal, discusión traída del derecho español y que inexplicablemente ha calado fuertemente en nuestra jurisprudencia. ${ }^{56} \mathrm{En}$ efecto, en el derecho español dicha construcción doctrinal arranca del Art. 25.1 de la Constitución Española que establece una garantía amplia a los ciudadanos respecto de la potestad punitiva del Estado en materia penal y administrativa, ${ }^{57}$ lo que claramente

${ }^{54}$ Nieto, A., Derecho Administrativo Sancionador, Tecnos, Madrid, 2 a edición, 1994, pp. 21-22.

${ }^{55}$ Así, a manera ejemplar, el Art. 19 del DFL N 3/1997, Ley General de Bancos, "las instituciones sometidas a la fiscalización de la Superintendencia que incurrieren en alguna infracción a la ley que las rige, a sus leyes orgánicas, a sus estatutos o a las órdenes legalmente impartidas por el Superintendente, que no tenga señalada una sanción especial, podrán ser amonestadas, censuradas o penadas con multa hasta por una cantidad equivalente a cinco mil unidades de fomento". En el mismo sentido, en materia de telecomunicaciones, el Art. 36 de la Ley 18.168, Ley General de Telecomunicaciones, dispone que "las infracciones a las normas de la presente ley, a sus reglamentos, planes técnicos fundamentales y normas técnicas, serán sancionadas por el Ministro en conformidad a las disposiciones de esta ley. Las sanciones sólo se materializarán una vez ejecutoriada la resolución que las imponga". Por último, en materia eléctrica también encontramos esta potestad sancionadora de la Administración del Estado, disponiendo el Art. $3 \mathrm{~N}^{\circ} 12$ y 23, respectivamente, la facultad de la Superintendencia de Electricidad y Combustibles para "amonestar, multar e incluso administrar provisionalmente el servicio a expensas del concesionario, si la calidad de un servicio público de distribución de recursos energéticos es reiteradamente deficiente" y "sancionar el incumplimiento de las normas técnicas y reglamentarias vigentes o que se establezcan en virtud de la legislación eléctrica, de gas y de combustibles líquidos relativas a las instalaciones correspondientes, con desconexión de éstas, multas o ambas medidas".

${ }^{56}$ En este sentido, el Tribunal Constitucional chileno ha señalado que "los principios inspiradores del orden penal contemplados en la Constitución Política de la República han de aplicarse, por regla general, al derecho administrativo sancionador, puesto que ambos son manifestaciones del ius puniendi propio del Estado" (STC 244/1996). Ello ha sido reiterado recientemente por el Excmo. Tribunal (STC 480/2006), expresando que "el principio de legalidad es igualmente aplicable a la actividad sancionadora de la administración en virtud de lo prescrito en los dos últimos incisos del numeral 3 del artículo 19 de la Carta Fundamental. Aun cuando las sanciones administrativas y las penas difieren en algunos aspectos, ambas pertenecen a una misma actividad sancionadora del Estado -el llamado ius puniendi- y están, con matices, sujetas al estatuto constitucional establecido en el numeral del artículo 19".

${ }^{57}$ El Art. 25.1 de la Constitución Española señala que "nadie puede ser condenado o sancionado por acciones u omisiones que en el momento de producirse no constituyan delito, falta o infracción administrativa, según la legislación vigente en aquel momento" (la cursiva es mía). 
no hace nuestra Constitución de 1980 -que únicamente se refiere a los principios de tipicidad y legalidad en materia penal-, aun cuando nuestros jueces extiendan analógicamente su aplicación. ${ }^{58}$

\section{Los privilegios de la Administración Pública y sus potestades}

Junto a las potestades administrativas antes enunciadas, nuestro ordenamiento también reconoce a la Administración del Estado una serie de privilegios en el ejercicio de las mismas potestades, los que también tienen su fundamento en el régimen especial reconocido a aquella para la tutela de los intereses públicos.

\section{a. La presunción de legalidad de los actos administrativos}

La presunción de legalidad de los actos administrativos es uno de los privilegios que sirve a la actuación de la Administración del Estado en un régimen administrativo. Este privilegio es una presunción iuris tantum que desplaza sobre los particulares la carga de impugnar el acto administrativo, evitando que éste se considere consentido. ${ }^{59}$ Así, esta presunción opera como una base para la aplicación inmediata del acto, sin requerir el acuerdo expreso del particular afectado, sin perjuicio de que éste puede ser paralizado e incluso dejarse sin efecto por los tribunales de justicia.

Su antecedente más remoto se encuentra en los antiguos privilegios que gozaban todas las actuaciones del príncipe, fundadas éstas en la racionalidad, equidad y prudencia que ostentaba éste. ${ }^{60}$ Evidentemente este fundamento ya no es de recibo en el actual Estado constitucional de Derecho y su subsistencia sólo puede tener asidero en la potencia general de que están revestidas todas las actuaciones del poder público ${ }^{61}$. Así, tanto el acto legislativo, el judicial como el administrativo están revestidos, en principio, de una presunción de validez que permite su ejecución inmediata, lo que impide su resistencia o desobediencia unilateral. Ello, en el ámbito administrativo, permite dar eficacia real

${ }^{58}$ En el derecho español, a partir de la entrada en vigencia de la Constitución de 1978 se ha establecido como un dogma irrefutable la fundamentación de la potestad sancionadora de la Administración en el marco del más general ius puniendi estatal. En este sentido, Nieto ha señalado que "tradicionalmente venía siendo considerada como una emanación de la Policía y desde allí se ha ido evolucionando hasta llegar a la tesis que hoy es absolutamente dominante, a saber: la potestad administrativa sancionadora, al igual que la potestad penal de los Jueces y Tribunales, forman parte de un genérico <<ius puniendi >> del Estado, que es único aunque luego se subdivide en estas dos manifestaciones" (la cursiva es del texto citado). Nieto, A., Derecho Administrativo Sancionador, ob. cit, p. 80.

${ }^{59}$ Ver, García Macho, R. y Blanco, J.L., “Autotutela Administrativa”, en Diccionario de Derecho Administrativo, Santiago Muñoz Machado (Director), Iustel, Madrid, 2005, tomo I A-G, p. 297.

${ }^{60}$ Villar Palasí, J.L., Técnicas remotas del Derecho Administrativo, ob. cit., pp. 27-28.

${ }^{61}$ En este sentido, De Otto explica con magistral claridad los fundamentos de la presunción de legitimidad constitucional de la ley, como expresión normativa de la voluntad popular, lo que impide la desobediencia directa de esta expresión de un poder público. De Otto, I., Derecho Constitucional. Sistema de fuentes, Ariel Derecho, Barcelona, $2^{a}$ edición, $5^{\text {a }}$ reimpresión, 1997, pp. 148-149. 
a las potestades administrativas, logrando una efectiva e inmediata protección de los intereses públicos, ${ }^{62}$ sin perjuicio de la necesaria protección de los derechos e intereses de especial protección constitucional y que impiden el ejercicio indiscriminado de la potestad de ejecución forzosa. ${ }^{63}$

Este privilegio ha sido tradicionalmente resistido por un sector de la doctrina nacional, impugnando en forma absoluta su procedencia sobre la base, principalmente, del derecho constitucional a la igualdad ante la ley y un mal entendido principio constitucional de juridicidad ${ }^{64}$ o admitiéndolo parcialmente respecto sólo de los actos administrativos tomados razón en forma favorable. ${ }^{65}$ No obstante, otro sector doctrinal reconoció desde siempre esta presunción de los actos administrativos, ${ }^{66}$ lo que hoy día tiene un fundamento expreso en la LBPA. En efecto, el Art. $3^{\circ}$ de esta ley estableció expresamente que "los actos administrativos gozan de una presunción de legalidad", privilegio que da cobertura a todos los actos emanados de la Administración del Estado.

\section{b. La ejecutividad, ejecutoriedad y ejecución forzosa de los actos administrativos}

Otro de los privilegios más emblemáticos de los actos emanados de la Administración del Estado es la posibilidad de ejecución inmediata y directa, sin necesidad de establecer previamente por los tribunales de justicia su conformidad al Derecho. Esta posibilidad de eficacia tiene su fundamento en la presunción de legalidad o validez que tendrían estos actos y puede implicar su obligatoriedad jurídica (ejecutividad), su potencialidad de ejecución coactiva (ejecutoriedad) y la disposición por la Administración del Estado de medios de ejecución forzosa directa (ejecución forzosa). En el fondo, se trata de reconocer a la Administración del Estado una potestad de autotutela declarativa y ejecutiva que le permite dotar a sus actos de una potencia y eficacia excepcionales dentro del orden jurídico, sin perjuicio de las facultades de revisión que ostentan los tribunales de justicia ${ }^{67}$.

El fundamento histórico de este privilegio de la Administración está dado por las prerrogativas originarias que detentaba el príncipe en el Estado absoluto, lo que le

${ }^{62}$ Ver Parejo, L., "La tutela judicial cautelar en el orden contencioso-administrativo", en Revista Española de Derecho Administrativo, Cívitas, No 49, enero-marzo 1986, versión CD Rom No 1-100, 1998, p. 3.

${ }^{63}$ En este sentido, Betancor señala que la eficacia de la acción administrativa no es homogénea en las diversas materias reguladas en el ordenamiento, sino que ella dependerá de los intereses y derechos en conflicto. Ver Betancor, A., El acto ejecutivo, Centro de Estudios Constitucionales, Madrid, 1992, pp. 442-443.

${ }^{64}$ Por todos, Soto, E., "La Ley 19.880, sobre procedimientos administrativos, ¿'Aleluya' o 'Miserere'?”, ob. cit., pp. 92 y 99, y Riveros de Gatica "La presunción de legalidad del acto administrativo: el artículo $3^{\circ}$ de la Ley 19.880 de procedimientos administrativos a la luz de la Constitución de 1980", en Ius Publicum, $\mathrm{N}^{\circ} 16,2006$, pp. 120-123.

${ }^{65}$ Ver Aróstica, I., "El trámite de toma de razón de los actos administrativos", en Revista de Derecho Público, No 49, 1991, pp. 164-166.

${ }^{66}$ Por todos, Silva Cimma, E., Derecho Administrativo chileno y comparado. Actos, contratos y bienes, Editorial Jurídica de Chile, Santiago, 1a edición, 1995, p. 103.

${ }^{67}$ García de Enterría, E. y Fernández, T.R., Curso de Derecho Administrativo, tomo I, ob. cit., pp. 491 494 y $555-556$. 
permitía no sólo declarar el derecho, sino disponer de vías de apremios para su cumplimiento $^{68}$. Más modernamente este privilegio lo explica la doctrina en la tendencia a la plenitud de las competencias administrativas de los órganos públicos, lo que deriva en último término de la fuerza ejecutiva de la ley, la que se concretaría dándole eficacia a la acción administrativa ${ }^{69}$.

En nuestro derecho, este privilegio ha sido explicado dogmáticamente a partir de la cláusula general de la protección del bien común establecida en la Constitución Política de la República (Art. $1^{\circ}$ ), lo que le permitiría a la Administración desplegar sus potestades exorbitantes como manifestación concreta de la soberanía del poder estatal. ${ }^{70}$ Sin embargo, pareciera más razonable, a mi juicio, fundar esta potestad de autotutela en nuestro derecho a partir simplemente del reconocimiento de poder público a la Administración del Estado, y como tal, atribuida de unas prerrogativas de ejecución de la ley en los ámbitos entregados a su esfera de competencia. Así, la actividad administrativa dispone, prima facie, de una fuerza ejecutiva como los demás actos de los órganos estatales, fuerza que deriva directamente del poder del Estado en un ordenamiento jurídico determinado.

Esto es lo que pareciera reconocer expresamente la LBPA, al establecer en su Art. $3^{\circ}$ que "los actos administrativos gozan de una presunción de legalidad, de imperio y exigibilidad frente a sus destinatarios, desde su entrada en vigencia, autorizando su ejecución de oficio por la autoridad administrativa..." , para luego añadir en el Art. 51, relativo a la ejecutoriedad, que "los actos de la Administración Pública sujetos al Derecho Administrativo causan inmediata ejecutoria...". Así es evidente que la fuerza ejecutiva de la actividad administrativa deriva del propio órgano emisor del acto, en la medida que cumpla con los requisitos de existencia establecidos en el mismo Art. $3^{\circ}$ LBPA.

Ahora bien, de estas normas se colige fácilmente que en el derecho chileno los actos emanados de los órganos de la Administración del Estado gozan de los privilegios de ejecutividad y ejecutoriedad, lo que les permite su ejecución inmediata sin intervención de los tribunales de justicia. ${ }^{71}$

Cuestión distinta es la ejecución forzosa de los actos administrativos, ya que ésta implica su ejecución directa y coactiva por la Administración, disponiendo de los medios jurídicos y materiales para ello. En esto la LBPA chilena no estableció -a diferencia de la española, que claramente le sirvió de referencia ${ }^{72}-$ instrumentos concretos para llevar

\footnotetext{
${ }^{68}$ Villar Palasí, J. L., Técnicas remotas del Derecho Administrativo, ob. cit., pp. 29-30.

${ }^{69}$ En este sentido, ver López, F., "Límites constitucionales de la autotutela administrativa, en Revista de Administración Pública, $\mathrm{N}^{\circ} 115$, enero-abril 1988, pp. 59-60.

${ }^{70}$ Aguerrea, P., "Las prerrogativas del acto administrativo en la Ley 19.880", en Ley 19.880, sobre Procedimientos Administrativos, ob. cit., p. 47.

${ }^{71}$ En el mismo sentido, Cordero, E., "La eficacia, extinción y ejecución de los actos administrativos en la Ley 19.880”, ob. cit., pp. 118-119.

${ }^{72}$ Como se puede observar, la Ley 30/1992, de Régimen Jurídico de las Administraciones Públicas y del Procedimiento Administrativo Común, establece entre sus Arts. 95 a 100 la ejecución forzosa y los medios de hacerla efectiva, mencionando el apremio sobre el patrimonio, la ejecución subsidiaria, la multa coercitiva y la compulsión sobre las personas como medios idóneos para ello.
} 
a ejecución directa sus actos, disponiendo sólo su ejecutoriedad. Esto lleva a pensar que en nuestro derecho la ejecución forzosa de los actos administrativos es una potestad o privilegio entregado, por regla general, a los tribunales de justicia, salvo que la ley disponga en un caso particular esta habilitación para la Administración, señalando al mismo tiempo los instrumentos específicos para hacerla efectiva. ${ }^{73}$

\section{c. Los privilegios procesales de la Administración Pública}

Junto a las prerrogativas administrativas anteriores, también existe una serie de privilegios procesales para la Administración del Estado. Entre ellos los más reconocidos son el llamado "solve et repete", la inembargabilidad de los bienes públicos y las vías especiales de ejecución de las sentencias condenatorias en contra de los órganos de la Administración.

\section{i. "Solve et repete"}

Este privilegio procesal, que en términos literales significa "paga y repite”, implica un condicionamiento de la admisibilidad de los reclamos administrativos o las acciones contencioso-administrativas en contra de multas u otras obligaciones dinerarias declaradas a favor de la Administración, al pago previo de ésta, o una fracción, por parte del particular afectado. ${ }^{74}$ En el fondo se trata de una limitación material a los particulares del acceso a la jurisdicción, fundada en la rigurosidad en el uso de las vías procedimentales de reclamo en contra de la Administración.

En el derecho comparado esta cláusula ha sido severamente cuestionada por la doctrina y jurisprudencia más citada, considerándose un límite inaceptable al derecho fundamental a la acción o tutela judicial. Así, en el derecho español, el Tribunal Supremo ha declarado expresamente que "desde la vigencia de la Constitución, han de estimarse derogados los preceptos que exigen el depósito previo, la consignación o aval por el importe de la multa para poder formular tanto un recurso administrativo como uno contencioso-administrativo, por causa del rechazo postconstitucional del principio solve et repete como requisito previo sine que non, para el logro de la tutela judicial en el ejercicio de derechos o intereses legítimos (Sentencias de 15 de marzo de 1985, de 19 de noviembre de 1987 y de 9 de octubre de 1991)". ${ }^{75}$

${ }^{73}$ En este punto puede consultarse la útil e interesante memoria de grado de Villar, H., La ejecución forzosa de los actos de la Administración en el derecho chileno, Facultad de Ciencias Jurídicas y Sociales, Universidad Austral de Chile, 2006.

${ }^{74}$ García Macho, R. y Blanco, J.L., “Autotutela Administrativa”, en Diccionario de Derecho Administrativo, ob. cit., tomo I A-G, p. 304.

${ }^{75}$ Idem, p. 304. 
En la doctrina nacional esta materia ha tenido aún escaso desarrollo, aunque algunos autores ya han manifestado sus objeciones a este privilegio de la Administración, ${ }^{76}$ lo que ha sido ratificado parcialmente por la reciente jurisprudencia del Tribunal Constitucional (STC 536/2006). En este caso, siguiendo los criterios expuestos en el derecho comparado, el criterio central ha sido cuestionar la constitucionalidad de este privilegio, atendidos los derechos fundamentales a la igualdad ante la ley (Art. $19 \mathrm{~N}^{\circ} 2$ CPR) ${ }^{77} \mathrm{y}$, especialmente, el derecho de acceso a la justicia (Art. $\left.19 \mathrm{~N}^{\circ} 3 \mathrm{CPR}\right)^{78}$ establecido en forma más o menos imprecisa en nuestra Carta Política.

No obstante, es evidente que en nuestra normativa infraconstitucional existe una serie de normas que establecen expresamente este mecanismo como requisito de acceso a los procedimientos judiciales de reclamo, fijándose un porcentaje de la multa reclamada como barrera de entrada. ${ }^{79}$ Ellas, en principio, podrían ser contrarias a la Constitución y como tales excluida su aplicación del ordenamiento jurídico; sin embargo nuestro Tribunal Constitucional ha limitado su inconstitucionalidad a los casos en que la consignación previa no se sujeta un límite máximo que garantice siempre a los particulares el acceso a la justicia. ${ }^{80}$ Esta doctrina incluso ha sido matizada posteriormente por el propio Tribunal (STC 546/2006), señalando -al menos la mitad de los ministros del mismo, que constituyeron el voto decisivo para la resolución final, al no haber mayoría para acoger el requerimiento- que no es posible establecer a priori en nuestro derecho la constitucionalidad o no de este privilegio, sino que debe ponderarse en cada caso la

${ }^{76}$ Por todos, Soto, E., "Solve et repete. Notas sobre un resabio absolutista en el Estado Constitucional de Derecho", en Ius Publicum, N 6, 2001, pp. 79 y ss., y Bocksang, G. El procedimiento administrativo chileno, Lexis Nexis, Santiago, 2006, pp. 62-66.

${ }^{77}$ Bocksang, G., El procedimiento administrativo chileno, ob. cit., p. 62.

${ }^{78}$ Soto, E., "Solve et repete", ob. cit., p. 86.

${ }^{79}$ Así, puede tenerse como ejemplo el Art. 69 de la Ley 18.880 Orgánica Constitucional del Banco Central de Chile que establece para la procedencia del reclamo de ilegalidad ante la Corte de Apelaciones de Santiago en contra del Banco Central por acuerdos, resoluciones, órdenes o instrucciones “deberá acompañarse boleta de consignación, a la orden del tribunal, por el equivalente al uno por ciento del monto total de la operación o del perjuicio que se reclama. Para el cálculo de este porcentaje se empleará el valor que resulte mayor. En todo caso, el monto máximo de la consignación no podrá ser superior a seiscientas unidades tributarias mensuales". En términos parecidos se contiene la exigencia de consignación previa para reclamar de las sanciones impuestas a una empresa por la Comisión Regional o Nacional del Medio Ambiente en caso de incumplimientos a la Declaración o Estudio de Impacto Ambiental, señalando que se podrá recurrir al juez "previa consignación al $10 \%$ del valor de la multa aplicada, en su caso, sin que esto suspenda el cumplimiento de la resolución revocatoria, y sin perjuicio del derecho del afectado a solicitar orden de no innovar ante el mismo juez de la causa" (Art. 64 de la Ley 19.300 de Bases del Medio Ambiente).

${ }^{80}$ Este criterio fue expuesto claramente por el Excmo. Tribunal en la STC 536/2006, disponiendo la inconstitucionalidad de la consignación previa para reclamar de una multa, pero no por la exigencia de ésta, sino por la falta de un límite máximo en la cantidad exigida, más allá del porcentaje asignado (1/3 de parte). Así sostiene que "la aludida exigencia de una consignación previa resulta así de carácter indeterminado, carente de un límite, pudiendo, en consecuencia, llegar a cantidades cuya cuantía, en la práctica, entraben más allá de lo razonable el derecho de acceso a la justicia, al restringir tan severamente la posibilidad de reclamar ante un tribunal de la multa impuesta por la autoridad administrativa. Ello resulta contrario a los derechos que asegura el artículo $19 \mathrm{~N}^{\circ} 1$ de la Carta Fundamental, en sus incisos primero y segundo, a la igual protección de la ley en el ejercicio de sus derechos y a la defensa jurídica...". 
consignación exigida en un procedimiento judicial y no evaluar la norma legal en abstracto para declarar su inconstitucionalidad. ${ }^{81}$

De lo anterior queda en evidencia que en nuestro derecho -al menos en la interpretación de nuestro más Alto Tribunal en la materia- el privilegio procesal de la Administración denominado "solve et repete" no es per se contrario a la Constitución, sino sólo cuando ella pudiera impedir -en términos abstractos- el efectivo acceso de los particulares a la jurisdicción

\section{ii. La inembargabilidad de los bienes públicos}

Otro de los privilegios procesales de la Administración es la garantía de inembargabilidad de ciertos bienes, no obstante existir una sentencia condenatoria en su contra. En otras palabras, constituye una excepción calificada que favorece a los órganos de la Administración del Estado, que impide que pueda operar en su contra una medida ordinaria de garantía del cumplimiento de sentencias condenatorias en dinero.

Este privilegio tiene sus antecedentes más remotos en la inmunidad de que gozaba el patrimonio del príncipe en la Edad Media y su fundamento estaba relacionado con el estatus privilegiado que ostentaba éste en el ordenamiento jurídico. ${ }^{82}$ Sin embargo, contemporáneamente, éste se sustenta en la vinculación que tienen estos bienes con el cumplimiento de fines, valores y principios constitucionales específicos, los que se relacionan con el funcionamiento regular y continuo de ciertos servicios públicos que satisfacen bienes relevantes para la comunidad, los cuales no pueden ser afectados gravemente por los intereses generales puestos en juego. ${ }^{83}$

En el derecho chileno, este privilegio está expresamente reconocido de forma general en nuestro Código de Procedimiento Civil al establecer la inembargabilidad de "los bienes destinados a un servicio que no puede paralizarse" (Art. $445 \mathrm{~N}^{\circ} 17$ ), pero que tiene una expresión más concreta en los bienes municipales. Así, el Art. 32 de la Ley Orgánica Constitucional de Municipalidades establece la inembargabilidad de los bienes municipales destinados a su funcionamiento y los dineros depositados a plazo o en cuenta corriente, norma que pareciera tener precisamente como fundamento la esencialidad de los servicios que presta esta entidad y que está asociada a esos bienes.

${ }^{81}$ Así, en la STC 546/2006, el mismo Tribunal no estableció la inconstitucionalidad de la exigencia de consignación porcentual de la multa sin límite, ya que no se daban los supuestos, en el caso concreto, para establecer una infracción a los derechos constitucionales del requirente.

${ }^{82}$ Villar Palasí. Técnicas remotas del Derecho Administrativo, ob. cit., p. 39.

${ }^{83}$ En el mismo sentido, Fernández-Fontecha, M., "La inembargabilidad de los fondos públicos. Análisis del alcance y limitaciones de los artículos 44 de la Ley General Presupuestaria y 18 de la Ley de Patrimonio del Estado”, en Gobierno y Administración en la Constitución, Dirección General del Servicio Jurídico del Estado, Instituto de Estudios Fiscales, Madrid, 1988, vol. I, pp. 580 y ss. El Tribunal Constitucional Español (STC 166/1998) ha acogido esta tesis, configurando esta regla de inembargabilidad de ciertos bienes públicos -con las condiciones y restricciones que allí señala- como una excepción calificada al derecho a la tutela judicial efectiva establecido en el artículo 24 de la Constitución española. 
Dicho privilegio ha sido severamente cuestionado por un sector de la doctrina comparada basado en el derecho fundamental a la tutela judicial efectiva de los derechos de las personas frente a los actos del poder público, derecho que se vería seriamente amagado al limitarse los medios procesales de garantía de sus acciones. ${ }^{84}$ En la doctrina nacional también se han levantado algunas voces críticas frente a este privilegio procesal, alegando una trasgresión evidente a los derechos constitucionales a la propiedad, a la igualdad ante la ley y a la igual protección de la ley en el ejercicio de sus derechos (Arts. 19 No 24, 2 y 3 CPR, respectivamente, y a la exclusividad de la función judicial que asigna nuestra Constitución a los tribunales de justicia (Art. $76 \mathrm{CPR}$ ). ${ }^{85}$ Los dos primeros argumentos no parecen suficientes para excluir a priori la validez de una norma diferenciada para la Administración Pública, sobre todo a partir de la objeción ideológica del régimen jurídico diferenciado para ésta. Cuestión distinta es la objeción que se plantea desde la perspectiva del derecho a la acción o la tutela judicial y su complemento la exclusividad de las facultades jurisdiccionales -incluyendo la ejecución de la sentencia- proclamada en nuestra Carta Fundamental, ya que es evidente que en ciertos casos este privilegio de la Administración podría transformarse en un impedimento efectivo del ejercicio de la función de juzgar encomendada a los tribunales de justicia y a la ejecución de la sentencia judicial ya dictada, cuestión que en todo caso debería acreditarse en cada caso concreto.

\section{iii. La ejecución de sentencias contra la Administración}

Complemento del privilegio anterior es el establecimiento de un procedimiento especial de ejecución de las sentencias condenatorias en contra de los órganos de la Administración del Estado. Se trata en verdad de un privilegio cuyos antecedentes se remontan a la afirmación estricta del principio de separación de poderes en el derecho galo, pero que hoy pervive fundado en la protección de los intereses públicos que pudieran verse afectados con la ejecución directa de la sentencia en los bienes públicos y el respeto del principio de legalidad presupuestaria que regula la ejecución del gasto público.

En el derecho chileno este privilegio opera como una regla general en la ejecución de las sentencias en contra del Fisco, disponiéndose al efecto que su forma de llevarla a cabo es mediante decreto expedido por el ministerio respectivo, el que deberá ser dictado dentro del plazo de 60 días de recibido el oficio del tribunal correspondiente. Además en los casos en que la sentencia involucre prestaciones de carácter pecuniario,

${ }^{84}$ Por todos, García de Enterría, E. y Fernández, T.R., Curso de Derecho Administrativo, tomo II, pp. 646647. Un estudio muy acucioso y actual de esta problemática en el Derecho español, con una buena síntesis de la doctrina y jurisprudencia más relevante puede verse en Ballesteros, L.A., "La doctrina del Tribunal Constitucional sobre el privilegio de inembargabilidad de los bienes y derechos públicos (comentario a la STC 166/1998, de 15 de julio)", en Revista de Administración Pública, No 148, enero-abril 1999, pp. 195 y ss.

${ }^{85}$ Soto, E., "Comentario: Recurso de Protección ante resoluciones judiciales. Embargabilidad de bienes municipales y protección de funcionarios públicos”, en Ius Publicum, No 2, 1999, pp. 237-242. 
el decreto ministerial deberá remitirse a la Tesorería General de la República para su pago efectivo (Art. 752 el Código de Procedimiento Civil).

Similar procedimiento ha establecido nuestro legislador para el cumplimiento de sentencias condenatorias en contra de las municipalidades, disponiéndose en estos casos la dictación de un decreto alcaldicio (Art. 32 Ley Orgánica Constitucional de Municipalidades). Sin embargo, en estos casos, la ley ha dispuesto también la procedencia de un mecanismo especial de apremio para el cumplimiento del fallo, el arresto del alcalde, pero siempre respecto de sentencias recaídas en deudas contraídas por el alcalde en su periodo alcaldicio.

Es evidente que las objeciones constitucionales expuestas en el punto anterior son plenamente aplicables a este caso, ya que el procedimiento especial de ejecución en contra de la Administración también puede considerarse como una grave alteración del principio de monopolio jurisdiccional establecido en el Art. 76 de la Constitución y una erosión del derecho a la acción o tutela judicial garantizado a todos los ciudadanos en el Art. $19 \mathrm{~N}^{\mathrm{o}} 3$ de la misma Carta. No obstante, la defensa nuevamente de este privilegio de la Administración estará fundada en los intereses públicos que ésta cautela, los que podrían verse seriamente afectados por la irrupción de una ejecución inmediata de una condena pecuniaria sobre aquella.

\section{La relectura de los privilegios de la Administración Pública en el Estado constitucional de Derecho}

\section{a. Los derechos de las personas y el control de las potestades administrativas}

Es claro que la vigencia plena de estos poderes y privilegios de la Administración requieren, en un Estado constitucional de Derecho, una contrapartida que haga efectivos los derechos de los ciudadanos frente al poder. En otras palabras, no sería admisible actualmente seguir reconociendo esta amplia gama de potestades exorbitantes de la Administración del Estado, sin que, por otra parte, se habilitaran mecanismos efectivos de control y garantía de los derechos de los ciudadanos frente al poder. ${ }^{86}$

Este propósito se satisface a través de los procedimientos administrativos y judiciales de control de la Administración estatal, siendo estos últimos los que mayor responsabilidad tienen en la protección efectiva de estos derechos. En efecto, la independencia orgánica de los jueces, unida a su estricto apego a la legalidad, configuran a la justicia administrativa en el principal instrumento de control y balance de las prerrogativas de los órganos administrativos. En este sentido, la configuración adecuada de las potestades exorbitantes de la Administración y su control, para que no devengan en arbitrarias,

${ }^{86}$ Ver Parejo, L., "La tutela judicial cautelar en el orden contencioso-administrativo", ob. cit., pp. 1-2. 
exigen un sistema eficaz de justicia administrativa, sin la cual no está plenamente asegurado el Estado de Derecho. ${ }^{87}$

En este contexto, es evidente que en nuestro Derecho esta premisa se encuentra seriamente debilitada. Por un lado, al no existir un sistema estructurado de justicia administrativa, sino sólo un conjunto de procedimientos generales y especiales de control de la actividad administrativa, de escasa profundidad y que confunde a menudo instancias administrativas y judiciales, lo que aminora su poder e independencia para actuar. ${ }^{88}$ Por otro, por la falta de un procedimiento general establecido para juzgar las actuaciones administrativas, carencia que difícilmente podrá suplir, por su naturaleza, la denominada "acción de nulidad de derecho público". Por último, por una distorsión absoluta en los mecanismos procesales de impugnación de los actos administrativos, en cuya labor ha contribuido largamente la aplicación extensiva del Recurso de Protección en estas materias. ${ }^{89}$

Dichos factores han impedido la configuración de una justicia administrativa eficaz que haga frente a las prerrogativas de la Administración del Estado, lo que ha llevado a un sector de la doctrina, equivocadamente a mi juicio, a poner un acento crítico en las potestades, más que en su control. En efecto, los cuestionamientos más incisivos sobre la juridicidad de las potestades de la Administración muestran una preocupación por impedir la acción administrativa en vez de controlar su ejercicio, asumiendo que aquella constituye una actividad irresistible para los particulares. Esto se aprecia claramente si se analizan los argumentos expuestos en contra de la autotutela administrativa, asumiendo que aquella constituye una manifestación ilegítima de la "potestad jurisdiccional" autoasignada por los órganos de la Administración. ${ }^{90}$

Lo anterior ha sido complementado con una confusión evidente en la configuración de esas mismas potestades, las que ya etiquetadas como jurisdiccionales son sometidas a unas exigencias constitucionales absurdas e improcedentes. Basta ver, en este sentido, los pronunciamientos de nuestro Excmo. Tribunal Constitucional en el último año (STC 472/2006, 499/2006, 521/2006 y 536/2006) para corroborar lo afirmado, en que la identificación de potestades administrativas resolutivas y sancionatorias de los órganos

${ }^{87}$ Téngase en cuenta que para la doctrina administrativa más citada, el Estado de Derecho, desde la perspectiva del Derecho Administrativo se compondría de tres principios o elementos principales: principio de legalidad de la función ejecutiva; principio de integridad patrimonial o equivalente económico; y principio de control judicial pleno de la actuación administrativa. Este último precisamente es el que equilibra las potestades administrativas y hace posible el control de la legalidad administrativa y la tutela de los derechos de los ciudadanos. Ver Parejo, L., Derecho Administrativo, pp. 94 y ss.

${ }^{88}$ En este sentido, y sobre la confusión en nuestra doctrina entre tribunales y órganos administrativos resolutivos y de los procedimientos que cada uno conoce, ver Bordalí, A. y Ferrada, J.C., "Las facultades juzgadoras de la Administración: una involución en relación al principio clásico de la división de poderes”, en Revista de Derecho, Universidad Austral de Chile, Vol. XIII, diciembre 2002, pp. 187 y ss.

${ }^{89}$ Ver Ferrada, J.C., "El Recurso de Protección como mecanismo de control contencioso administrativo", en La Justicia Administrativa, J.C., Ferrada (Coor.), Lexis Nexis, Santiago, 2005, pp. 142 y ss.

${ }^{90}$ Ferrada, J.C., "Tutela y configuración del derecho fundamental a un juez predeteminado por la ley y potestades administrativas", en Justicia Constitucional y Derechos Fundamentales, A. Bordalí (Coor.), Lexis Nexis, Santiago, 2006, pp. 146 y ss. 
administrativos con "facultades jurisdiccionales" es evidente, lo que de paso confirma las limitaciones conceptuales de nuestra jurisprudencia.

En suma, parece incontrovertible que para hacer una lectura moderna y actual de las prerrogativas de la Administración Pública se requiere con urgencia en nuestro Derecho una justicia administrativa eficaz, ya que de otro modo aquellas no tienen contrapeso y se tornan para un buen sector de la doctrina no sólo exorbitantes, sino irresistibles.

\section{b. La justicia cautelar como instrumento privilegiado de control}

Un segundo aspecto que requiere abordarse de forma urgente en nuestro Derecho como contrapeso a las potestades administrativas, es la existencia de una verdadera justicia cautelar. La doctrina comparada ha venido insistiendo desde ya hace un tiempo la importancia que tiene la justicia cautelar en la tutela efectiva de los derechos de los ciudadanos y en el control de la legalidad de los actos administrativos, ${ }^{91}$ sobre todo a partir de la afirmación de la presunción de validez de éstos y la ejecutividad y ejecutoriedad de que están dotados. ${ }^{92}$ En el fondo, se trata de equilibrar la prerrogativa pública establecida en el ordenamiento a favor de la Administración, reconociéndoles a los ciudadanos un instrumento de tutela y control eficiente.

Pues bien, en nuestro Derecho no se ha tomado aún clara conciencia de ello. Nuevamente, como ya se expuso, un sector de la doctrina en vez de abogar por un fortalecimiento de la justicia cautelar en los procedimientos judiciales de reclamo, ha proclamado la inconstitucionalidad de la presunción de validez de los actos administrativos, así como de todo privilegio de ejecutividad y ejecutoriedad. ${ }^{93}$ Esto, como ya se expuso, no parece muy razonable y descansa más en una aproximación ideológica del tema más que en un trabajo serio de la dogmática jurídica.

En este contexto, parece indispensable revisar los alcances que ha tenido tradicionalmente la justicia cautelar en materia de justicia administrativa en nuestro medio, superando la limitada "orden de no innovar" como medida cautelar especial en ciertos procedimientos de control. En efecto, si bien esta medida tiene la virtud de paralizar de inmediato la actividad administrativa, su ámbito de aplicación es limitado, restringiéndose al Recurso de Protección y otros reclamos especiales de control de legalidad de actos administrativos, pero no aplicándose al procedimiento de nulidad de derecho público u otros procedimientos especiales de revisión de la legalidad de la actuación administrativa.

Lo anterior impone promover el desarrollo de una justicia cautelar más efectiva, ya sea con base en la habilitación a los jueces para decretar medidas innominadas de

${ }^{91}$ Ver, por todos, Chinchilla, Carmen, La tutela cautelar en la nueva Justicia Administrativa, Civitas, Madrid, 1991, pp. 28-30.

${ }^{92}$ García Macho, R. y Blanco, J.L., “Autotutela Administrativa”, en Diccionario de Derecho Administrativo, ob. cit., tomo I A-G, p. 303.

${ }^{93}$ Soto, E., "La Ley 19.880, sobre procedimientos administrativos, ¿'Aleluya' o 'Miserere'?”, ob. cit., pp. 92 y ss. 
cautela en los procedimientos judiciales (Art. 298 del Código de Procedimiento Civil), ya en la interpretación extensiva de las medidas establecidas en el Art. 290 del Código de Procedimiento Civil. Sin embargo, este último camino pareciera ser un poco inconsistente, sobre todo considerando el contenido real de las medidas allí establecidas.

\section{CONCLuSiones}

1. En el Derecho Administrativo chileno existen un conjunto de potestades y privilegios de la Administración del Estado cuyo fundamento y contenido está expresamente establecido en el ordenamiento.

2. Estas potestades y privilegios de la Administración tienen su fundamento en el propio "régimen administrativo" chileno, el que tiene sus antecedentes en el derecho francés y español consecutivamente, aunque modulados y adaptados a nuestro sistema jurídico.

3. El cuestionamiento de estas prerrogativas de la Administración por un sector de la doctrina nacional responde más a un enfoque ideológico que a una interpretación jurídica, lo que se ve corroborado por su recurso a argumentos tradicionales del derecho anglosajón del siglo XIX.

4. La confusión de nuestra jurisprudencia acerca de la existencia y el contenido de estas potestades administrativas descansa en una falta de identificación de los principios de nuestro sistema administrativo, resolviendo los asuntos sometidos a su decisión de una forma episódica y accidental, sin tener clara conciencia de las opciones ideológicas y jurídicas que adopta.

5. Una adecuada configuración de estas potestades y privilegios de la Administración en nuestro Derecho requiere una definición clara de su contenido y aplicación y la estructuración de una justicia administrativa eficaz, requisito este último ineludible para balancear adecuadamente potestades de la Administración y derechos de los ciudadanos.

\section{BIBLIOGRAFÍA}

Aguerrea, P., "Las prerrogativas del acto administrativo en la Ley No 19.880", en Ley 19.880, sobre Procedimientos Administrativos, Conferencias Santo Tomás de Aquino, Academia de Derecho Santo Tomás de Aquino. Universidad Santo Tomás, Santiago, 2003, pp. 45-50.

Amunátegui, J.D., Tratado general de Derecho Administrativo, Imprenta, Litografía y Encuadernación Barcelona, Santiago, 1907.

ArósticA, I., "El trámite de toma de razón de los actos administrativos", en Revista de Derecho Público, No 49, 1991, pp. 131-168. 
Aylwin, A. y Azócar, E., Derecho Administrativo, Universidad Nacional Andrés Bello, Santiago, 1996.

Ballesteros, L.A., "La doctrina del Tribunal Constitucional sobre el privilegio de inembargabilidad de los bienes y derechos públicos (comentario a la STC 166/1998, de 15 de julio)", en Revista de Administración Pública, No 148, enero-abril 1999, pp. 195 y ss.

Betancor, A., El acto ejecutivo, Centro de Estudios Constitucionales, Madrid, 1992

Bocksang, G., El procedimiento administrativo chileno, Lexis Nexis, Santiago, 2006.

Bordalí, A. y Ferrada, J.C., "Las facultades juzgadoras de la Administración: una involución en relación al principio clásico de la división de poderes”, en Revista de Derecho, Universidad Austral de Chile, Vol. XIII, diciembre 2002, pp. 187-205.

Caldera, H., Tratado de Derecho Administrativo, Ediciones Parlamento, Santiago, 2001.

CÁrdenas, D., El Consejo de Estado como tribunal contencioso-administrativo bajo la vigencia de la Constitución de 1833, Facultad de Ciencias Jurídicas y Sociales, Universidad Austral de Chile, 2004.

Chinchilla, C., La tutela cautelar en la nueva Justicia Administrativa, Civitas, Madrid, 1991, pp. 28-30.

Cordero Q., E., "La eficacia, extinción y ejecución de los actos administrativos en la Ley No 19.880", en Acto y Procedimiento Administrativo, Segundas Jornadas de Derecho Administrativo. ACTAS. Ediciones Universitarias de Valparaíso, Pontificia Universidad Católica de Valparaíso, Valparaíso, s.f., pp. 109-130.

De la Cuétara, J. M., "Potestades administrativas y poderes constitucionales: en torno al proceso de juridificación del poder”, en Revista Española de Derecho Administrativo, Cívitas, № 38 , septiembre-diciembre 1983, versión CD Rom No 1-100, 1998, p. 1-19.

De la Cuétara, J.M., Las potestades administrativas, Tecnos (Temas clave de la Constitución Española), Madrid, 1986.

De Oтto, I., Derecho Constitucional. Sistema de fuentes, Ariel Derecho, Barcelona, 1997, 2a edición, $5^{\text {a }}$ reimpresión.

DiCEY, A., Introduction to the study of the Law of the Constitution, Liberty Fund, Indianapolis, 1982, reimpresión $8^{a}$ edition, 1915.

El Ladrillo. Bases de la política económica del Gobierno militar chileno, Centro de Estudios Públicos, Santiago, 1992.

Fernández-Fontecha, M., "La inembargabilidad de los fondos públicos. Análisis del alcance y limitaciones de los artículos 44 de la Ley General Presupuestaria y 18 de la Ley de Patrimonio del Estado", en Gobierno y Administración en la Constitución, Dirección General del Servicio Jurídico del Estado, Instituto de Estudios Fiscales, Madrid, 1988, vol. I, pp. 580 y ss.

Ferrada, J.C., "La progresiva constitucionalización del poder público administrativo chileno: un análisis jurisprudencial", en La constitucionalización del derecho chileno, Editorial Jurídica de Chile / Universidad Austral de Chile, Santiago, 2003, pp. 63-98.

Ferrada, J.C., "La potestad invalidatoria de los órganos de la Administración del Estado", en Acto y Procedimiento Administrativo, Segundas Jornadas de Derecho Administrativo. ACTAS. Ediciones Universitarias de Valparaíso, Pontificia Universidad Católica de Valparaíso, Valparaíso, s.f., pp. 131-147.

Ferrada, J.C., "El Recurso de Protección como mecanismo de control contencioso administrativo", en La Justicia Administrativa, JC. Ferrada (Coor.), Lexis Nexis, Santiago, 2005, pp. 129-164.

Ferrada, J.C., "Tutela y configuración del derecho fundamental a un juez predeteminado por la ley y potestades administrativas”, en Justicia Constitucional y Derechos Fundamentales, A. Bordalí (Coor.), Lexis Nexis, Santiago, 2006, pp. 129-153. 
Fiamma, G., "El régimen administrativo tutelado", en Gaceta Jurídica, No 71, 1986, pp. 7-10. García de Enterría, E. y Fernández, T.R., Curso de Derecho Administrativo, Civitas, Madrid, $7^{a}$ edición, tomos I, 1996 y II, 4a edición, reimpresión, 1997.

García de Enterría, E., La lengua de los derechos. La formación del Derecho Público europeo tras la Revolución Francesa, Alianza Universidad, Madrid, reimpresión, 1995.

García Macho, R. y Blanco, J.L., "Autotutela Administrativa”, en Diccionario de Derecho Administrativo, Santiago Muñoz Machado (Director), Iustel, Madrid, 2005, tomo I A-G, pp. 294-305.

Giannini, M.S., El poder público. Estado y Administraciones Públicas, Civitas, Madrid, 1991.

Huneeus, J., La Constitución ante el Congreso, Vol. II, Imprenta de Los Tiempos, Santiago, 1879.

Lastarria, J.V., Estudios Políticos i Constitucionales, Imprenta, Litografía i Encuadernación Barcelona, Santiago, 1906.

LóPEZ, F., "Límites constitucionales de la autotutela administrativa, en Revista de Administración Pública, No 115 , enero-abril 1988, pp. 57-97.

Nieto, A., Derecho Administrativo Sancionador, Tecnos, Madrid, 2a edición, 1994.

Pantoja, R., El Derecho Administrativo. Concepto, características, sistematización, prospección, Editorial Jurídica de Chile, Santiago, 1996.

Pantoja, R., "El concepto de Derecho Administrativo en el Derecho chileno", en Revista de Derecho Público, No 64, 2002, pp. 189-212.

Parada, R., Derecho Administrativo, Marcial Pons, Madrid, 9a edición, 1997.

Parejo, L., El concepto del Derecho Administrativo, Editorial Jurídica Venezolana, Caracas, 1984.

Parejo, L., Derecho Administrativo, Ariel Derecho, Barcelona, 2003.

PAREJO, L., "La tutela judicial cautelar en el orden contencioso-administrativo", en Revista Española de Derecho Administrativo, Civitas, $\mathrm{N}^{\circ}$ 49, enero-marzo 1986, versión CD Rom $\mathrm{N}^{\circ}$ 1-100, 1998, pp. 1-22.

Prado, S., Principios elementales de Derecho Administrativo chileno, Imprenta Nacional, Santiago, 1859.

Riveros de Gatica, "La presunción de legalidad del acto administrativo: el artículo $3^{\circ}$ de la Ley $\mathrm{N}^{\circ} 19.880$ de procedimientos administrativos a la luz de la Constitución de 1980", en Ius Publicum, No 16, 2006, pp. 117-124.

Santamaría Pastor, J. A., Principios de Derecho Administrativo General, Iustel, Madrid, $1^{a}$ edición, reimpresión, 2005.

Santamaría Pastor, J. A., Sobre la génesis del Derecho Administrativo español en el siglo XIX (18121845), Iustel, Madrid, 2006.

Silva Bascuñán, A., Tratado de Derecho Constitucional, tomo V La Constitución de 1980 Gobierno, Editorial Jurídica de Chile, $2^{a}$ edición, 2000.

Silva Cimma, E., Derecho Administrativo chileno y comparado. Tomo I Introducción y fuentes, Editorial Jurídica de Chile, Santiago, 1954.

Silva Cimma, E., Derecho Administrativo chileno y comparado. Introducción y fuentes, Editorial Jurídica de Chile, Santiago, $4^{a}$ edición, 1996.

Silva Cimma, E., Derecho Administrativo chileno y comparado. Actos, contratos y bienes, Editorial Jurídica de Chile, Santiago, $1^{a}$ edición, 1995.

Sosa, F., Maestros alemanes del derecho público, Vol. I, Marcial Pons, Madrid, 2002.

Soто, E., "La Ley 19.880 sobre procedimientos administrativos, ¿'Aleluya' o 'Miserere'?”, en Ley $N^{o} 19.880$, sobre procedimientos administrativos. Conferencias Santo Tomás de Aquino, Academia de Derecho Santo Tomás de Aquino. Universidad Santo Tomás, Santiago, 2003, pp. 75-106. 
Soto, E., Derecho Administrativo, tomos I y II, Editorial Jurídica de Chile, Santiago, 1992.

Soтo, E., "La invalidación de los actos administrativos en el derecho chileno", en Revista de Derecho y Jurisprudencia, tomo LXXXV, № 3, septiembre-diciembre 1988, pp. 157-167.

Soto, E., "Solve et repete. Notas sobre un resabio absolutista en el Estado Constitucional de Derecho", en Ius Publicum, No 6, 2001, pp. 79-100.

Soto, E., "Comentario: Recurso de Protección ante resoluciones judiciales. Embargabilidad de bienes municipales y protección de funcionarios públicos”, en Ius Publicum, No 2, 1999, pp. 234-243.

Triepel, H., Derecho Público y política, Cuadernos Civitas, Madrid, 1a reimpresión, 1986.

Varas, G., Derecho Administrativo, Editorial Nascimento, Santiago, 1940.

Vedel, G., Derecho Administrativo, Biblioteca Jurídica Aguilar, Madrid, 1980.

VÉlez, J., Los dos sistemas del Derecho Administrativo, Institución Universitaria Sergio Arboleda, Santa Fe de Bogotá, $2^{a}$ edición, 1996.

Villar, H., La ejecución forzosa de los actos de la Administración en el derecho chileno, Facultad de Ciencias Jurídicas y Sociales, Universidad Austral de Chile, 2006.

Villar Palasí, J.L., Técnicas remotas del Derecho Administrativo, Instituto Nacional de Administración Pública, Madrid, 2001.

WeIL, P., Derecho Administrativo, Civitas, Madrid, 1986. 